\title{
Pengaruh Kompetensi Dan Pelatihan Terhadap Prestasi Kerja Relawan Pajak Tax Center Universitas Jember
}

\author{
Galih Wicaksono \\ Universitas Jember \\ e-mail: Galih.fisip@unej.ac.id

\begin{tabular}{ccc}
\hline Diterima & Direvisi & Disetujui \\
$22-02-2020$ & $03-03-2020$ & $06-03-2020$ \\
\hline
\end{tabular}

\begin{abstract}
Abstrak - Penelitian ini bertujuan untuk mengetahui pengaruh kompetensi dan pelatihan yang dimiliki oleh Relawan Pajak Tax Center Universitas Jember terhadap prestasi kerja yang dihasilkan. Penelitian ini merupakan jenis penelitian kuantitatif, yaitu metode penelitian yang berlandaskan pada filsafat positivisme, digunakan untuk meneliti pada populasi atau sampel tertentu, pengumpulan data menggunakan instrument penelitian, analisis data bersifat kuantitatif statistik, dengan tujuan untuk menguji hipotesis yang telah ditetapkan. Penelitian ini dilaksanakan pada Tax Center Universitas Jember. Pada penelitian ini, instrumen penelitian berupa kuesioner. Kuesioner tersebut akan dibagikan kepada responden sejumlah 59 orang relawan pajak tax center Universitas Jember, kemudian akan diolah secara statistik dengan software SPSS. Penelitian ini menghasilkan temuan bahwa secara parsial dan simultan, kompetensi dan pelatihan berpengaruh secara signifikan dan positif terhadap prestasi kerja. Sehingga jika terjadi peningkatan kompetensi dan pelatihan, maka akan meningkatkan pula prestasi kerja. Begitupula sebaliknya, jika terjadi penurunan kompetensi dan pelatihan, maka akan diikuti pula dengan adanya penurunan prestasi kerja. Sebesar 59,8\% perubahan yang terjadi pada prestasi kerja Relawan Pajak Tax Center Universitas Jember dijelaskan dengan baik oleh kompetensi dan pelatihan.
\end{abstract}

Kata Kunci : Kompetensi, Pelatihan, Prestasi

\begin{abstract}
This study aims to determine the effect of competence and training owned by Jember University Tax Center Volunteers on work performance generated. This research is a type of quantitative research, which is a research method based on the philosophy of positivism, used to examine populations or specific samples, collecting data using research instruments, analyzing quantitative quantitative data, with the aim to test the hypotheses that have been set. This research was conducted at the Jember University Tax Center. In this study, the research instrument was in the form of a questionnaire. The questionnaire will be distributed to 59 respondents from the Jember University tax center volunteer, then will be processed statistically with SPSS software. This research produces findings that partially and simultaneously, competence and training have a significant and positive effect on work performance. So that if there is an increase in competence and training, it will also increase work performance. Likewise on the contrary, if there is a decrease in competence and training, it will also be followed by a decrease in work performance. 59.8\% of the changes that occur in Jember University's Tax Center Volunteer Tax work performance are well explained by competence and training.
\end{abstract}

Keywords : Competence, Training, Achievement

\section{PENDAHULUAN}

Prestasi kerja adalah komponen penting dalam kemajuan suatu organisasi. Menurut Hasibuan (2015), prestasi kerja adalah suatu hasil kerja yang dicapai seseorang dalam melaksanakan tugas-tugas yang dibebankan kepadanya yang didasarkan atas kecakapan, pengalaman, kesungguhan, serta waktu. Lebih lanjut menurut Mangkunegara (2002), prestasi kerja adalah hasil kerja secara kualitas dan kuantitas yang dicapai oleh seseorang dalam melaksanakan tugansya sesuai dengan tanggungjawab yang dibebankan kepadanya. Setiap orang dalam suatu organisasi perlu memiliki sikap yang berprestasi, yang diwujudkan dalam bentuk prestasi kerja. Adanya prestasi kerja ini akan meningkatkan kinerja bagi organisasi secara keseluruhan. Untuk konteks relawan pajak pada tax center Universitas Jember, terdapat data bahwa jumlah relawan pada tahun 2020 sejumlah 59 orang, sehingga perlu diketahui terkait faktor-faktor yang berkaitan dengan prestasi kerja untuk menunjang kinerja tax center.

Kompetensi adalah salah satu faktor yang mendukung dalam pencapaian prestasi kerja relawan pajak. Menurut Aprilda (2017), kompetensi merupakan suatu kemampuan untuk melaksanakan atau melakukan suatu pekerjaan atau tugas, yang dilandasi atas keterampilan dan pengetahuan, serta 
didukung oleh sikap kerja yang dituntut oleh pekerjaan tersebut. Apabila relawan pajak memiliki kompetensi yang baik, tentu saja hal tersebut akan meningkatkan prestasi kerja. Hal tersebut sesuai dengan hasil penelitian oleh Aprilda (2017), Juned, dkk (2016), Yunus (2014), Firstie dan Madina (2017), serta Riyanda (2017), yang menemukan bahwa kompetensi berpengaruh positif dan signifikan terhadap prestasi kerja pegawai, yaitu apabila kompetensi meningkat maka tentu saja akan meningkatkan prestasi kerja pegawai, yang dalam hal ini adalah relawan pajak tax center Universitas Jember.

Pelatihan pajak juga dibutuhkan dalam rangka meningkatkan prestasi kerja relawan pajak, yaitu untuk meningkatkan pengetahuan, kemampuan, koreksi terhadap kekurangan individu, dalam hal ini akan meningkatkan kompetensi relawan sesuai dengan Peraturan Pemerintah No. 101 Tahun 2000 tentang Pendidikan dan Pelatihan, yaitu bahwa pendidikan dan pelatihan adalah proses penyelenggaraan belajar mengajar dalam rangka meningkatkan kemampuan. Hasil penelitian Sultana dkk (2012) menunjukkan bahwa pelatihan merupakan elemen kunci untuk meningkatkan kinerja, serta meningkatkan kompetensi individu dan organisasi. Kebutuhan pelatihan adalah setiap kekurangan dalam kinerja atau kinerja potensial yang dapat diatasi dengan pelatihan yang tepat. Sehingga diharapkan apabila relawan memperoleh pelatihan yang tepat, diharapkan akan meningkatkan prestasi kerja relawan pajak tax center. Hal ini sesuai dengan hasil penelitian Nurasiah (2016) dan Maulana (2016) yang menemukan bahwa pelatihan berpengaruh positif dan signifikan terhadap prestasi kerja, sehingga apabila pelatihan meningkat, maka diharapkan akan meningkatkan prestasi kerja karyawan, yang dalam hal ini adalah relawan pajak tax center Universitas Jember.

Kompetensi dan pelatihan yang perlu dimiliki oleh relawan pajak terkait dengan bidang keilmuan pajak, yaitu pajak pusat dan pajak daerah. Pajak pusat berfokus pada pajak penghasilan orang pribadi. Sedangkan pajak daerah terbagi menjadi dua, yaitu pajak provinsi dan pajak kabupaten atau kota (Wicaksono dan Pamungkas, 2017). Untuk pajak kabupaten / kota terdiri dari : pajak hotel, pajak restoran, pajak hiburan, pajak reklame, pajak penerangan jalan, pajak mineral bukan logam dan batuan, pajak parkir, pajak air tanah, pajak sarang burung walet, pajak bumi dan bangunan pedesaan dan perkotaan, dan bea perolehan ha katas tanah dan bangunan (Puspita dan Wicaksono, 2017).

Berdasarkan beberapa penelitian terdahulu, terdapat beberapa faktor yang terbukti berpengaruh terhadap prestasi kerja. Hasil penelitian Aprilda (2017), Juned, dkk (2016), Yunus (2014), Firstie dan Madina (2017), dan Riyanda (2017) menghasilkan temuan bahwa Kompetensi berpengaruh terhadap Prestasi Kerja. Selain itu, Pelatihan juga berpengaruh terhadap Prestasi Kerja, sebagaimana hasil temuan penelitian oleh Nurasiah (2016) dan Maulana (2016). Dengan adanya daya dukung berbagai faktor tersebut, tentu saja berkontribusi dalam peningkatan Prestasi Kerja, sehingga akan memacu kinerja organisasi yang lebih baik.

Prestasi kerja adalah hasil kerja yang dicapai oleh seseorang atau sekelompok orang dalam suatu organisasi, sesuai dengan wewenang dan tanggung jawab masing-masing dalam rangka upaya mencapai tujuan organisasi bersangkutan secara legal, tidak melanggar hukum dan sesuai dengan moral atau etika (Wahyudi, 2009). Prestasi kerja adalah tingkat keberhasilan dalam melaksanakan tugas, serta kemampuan untuk mencapai tujuan yang telah ditetapkan. Kinerja dikatakan baik dan sukses jika tujuan yang diinginkan dapat tercapai dengan baik. Prestasi kerja adalah hasil kerja secara kualitas dan kuantitas yang dicapai seorang karyawan dalam melaksanakan tugasnya sesuai dengan tanggung jawab yang diberikan kepadanya (Mangkunegara, 2006). Berdasarkan beberapa definisi yang dikemukakan dapat dikatakan bahwa prestasi kerja merupakan tingkat keberhasilan suatu pekerjaan dibandingkan dengan standar yang telah ditentukan sebelumnya pada perdiode tertentu, jika hasil kerja sesuai dengan standar yang ditetapkan maka seorang karyawan dikatakan memiliki prestasi kerja yang baik.

Bagi organisasi, hasil penilaian prestasi kerja para pegawai sangat penting arti dan peranannya dalam pengambilan keputusan, dimana faktor yang mempengaruhi pencapaian prestasi kerja diantaranya kepemimpinan, kompensasi yang adil dan suasana atau iklim kerja yang baik serta kesejahteraaan karyawan yang terpenuhi. Faktorfaktor yang mempengaruhi prestasi kerja adalah (Hasibuan, 2005) :

a. Kuantitas kerja, yaitu banyaknya hasil kerja sesuai dengan waktu kerja yang ada.

b. Kualitas kerja, yaitu mutu hasil kerja yang didasarkan pada standar yang ditetapkan. Biasanya diukur melalui ketepatan, ketelitian, keterampilan, dan kebersihan hasil kerja.

c. Keandalan, yaitu dapat tidaknya karyawan diandalkan adalah kemampuan memenuhi atau mengikuti instruksi, inisiatif, hati- hati, kreatif, dan kerja sama.

d. Inisiatif, yaitu kemampuan mengenali masalahmasalah dan mengambil tindakan korektif, memberikan saran-saran untuk peningkatan dan menerima tanggung jawab menyelesaikan tugastugas yang belum diberikan.

e. Kerajinan, adalah kesediaan melakukan tugas tanpa adanya paksaan dan yang bersifat rutin.

f. Sikap, yaitu perilaku karyawan terhadap perusahaan atau atasan dan teman sekerja.

g. Kehadiran, yaitu keberadaan karyawan di tempat kerja untuk bekerja sesuai dengan waktu atau jam kerja yang telah diestimasikan. 
Menurut Sedarmayanti (2010) kompetensi pada umumnya diartikan sebagai kecakapan, keterampilan, kemampuan. Kata dasarnya kompeten, berarti cakap, mampu atau terampil. Pada konteks manajemen sumber daya manusia, istilah kompetensi mengacu kepada atribut/karakteristik seseorang yang membuatnya berhasil dalam pekerjaan. Kompetensi sebagai pengetahuan keahlian, kemampuan, atau karakteristik pribadi individu yang mempengaruhi secara langsung kinerja pekerjaan. Kompetensi menggambarkan dasar pengetahuan dan standar kinerja yang dipersyaratkan agar berhasil menyelesaikan suatu pekerjaan atau memegang suatu jabatan.

Dari pengertian kompetensi tersebut di atas, terlihat bahwa fokus kompetensi adalah untuk memanfaatkan pengetahuan dan ketrampilan kerja guna mencapai kinerja optimal. Dengan demikian kompetensi adalah segala sesuatu yang dimiliki oleh seseorang berupa pengetahuan ketrampilan dan faktor-faktor internal individu lainnya untuk dapat mengerjakan sesuatu pekerjaan. Dengan kata lain, kompetensi adalah kemampuan melaksanakan tugas berdasarkan pengetahuan dan ketrampilan serta sikap yang dimiliki setiap individu.

Adapun yang menjadi komponen utama kompetensi sumber daya manusia menurut Wahyudi (2009), yaitu :

1. Pengetahuan yang berkaitan dengan pekerjaan, meliputi :

a. Mengetahui dan memahami pengetahuan di bidangnya masingmasing yang menyangkut tugas dan tanggung jawabnya dalam bekerja.

b. Mengetahui pengetahuan yang berhubungan dengan peraturan, prosedur, tehnik yang baru dalam perusahaan.

c. Mengetahui bagaimana menggunakan informasi, peralatan dan taktik yang tepat dan benar.

2. Keterampilan individu, meliputi :

a. Kemampuan dalam berkomunikasi dengan baik secara tulisan.

b. Kemampuan dalam berkomunikasi dengan jelas secara lisan.

3. Sikap kerja, meliputi :

a. Memiliki kemampuan dalam berkreativitas dalam bekerja.

b. Adanya semangat kerja yang tinggi.

c. Memiliki kemampuan dalam perencanaan/pengorganisasian.

Pelatihan merupakan kegiatan yang lebih banyak ditunjukkan pada pengembangan pegawai baik dalam bidang kecakapan, pengetahuan, keterampilan, keahlian, sikap dan tingkah laku pegawai serta lebih kepada sifat praktis. Efisensi suatu perusahaan sangat tergantung pada tingkat kualitas sumber daya manusia yang dimiliki oleh perusahaan. Menyadari peran penting sumber daya manusia yang berkualitas maka salah satu cara yang dilakukan pemerintah adalah melalui kegiatan pelatihan kerja.

Menurut Peraturan Pemerintah No. 101 tahun 2000 menyatakan bahwa adalah proses penyelenggaraan belajar mengajar dalam rangka menungkatkan kemampuan pegawai negeri sipil yang bertujuan untuk meningkatkan pengetahuan, keahlian, keterampilan dan sikap untuk dapat melaksanakan tugas jabatan secara profesional, menciptakan aparatur yang mampu berperan sebagai pembaharu dan perekat persatuan kesatuan bangsa, memantapkan sikap dan semangat pengabdian yang berorientasi pada pelayanan, pengayoman dan pembedayaan masyarakat, menciptakan kesamaan visi dan dinamika pola pikir dalam melaksanakan tugas pemerintahan umum dan pembangunan demi terwujud kepemerintahan yang baik. Pendidikan dan pelatihan merupakan salah satu upaya pengembangan pegawai dalam rangka memenuhi kinerja yang diharapkan dan memenuhi kualifikasi sumber daya manusia untuk menghadapi perubahan tuntutan kualitas baik dari internal maupun eksternal. Selain itu, Instansi pemerintah juga berperan dalam mengelola keuangan publik (Boedijono, dkk, 2019).

Indikator-indikator pelatihan menurut Mangkunegara (2006), diantaranya:

1. Instruktur

Mengingat pelatih umumnya berorientasi pada peningkatan skill, maka para pelatih yang dipilih untuk memberikan materi pelatihan harus benarbenar memiliki kualifikasi yang memadai sesuai bidangnya, personal dan kompeten, selain itu pendidikan instruktur pun harus benar-benar baik untuk melakukan pelatihan.

2. Peserta

Peserta pelatihan tentunya harus diseleksi berdasarkan persyaratan tertentu dan kualifikasi yang sesuai.

3. Materi

Pelatihan sumber daya manusia merupakan materi atau kurikulum yang sesuai dengan tujuan pelatihan sumber daya manusia yang hendak dicapai oleh perusahaan dan materi pelatihan pun harus update agar si peserta dapat memahami masalah yang terjadi pada kondisi yang sekarang.

4. Metode

Metode pelatihan akan lebih menjamin berlangsungnya kegiatan pelatihan sumber daya manusia yang efektif apabila sesuai dengan jenis materi dan komponen peserta pelatihan.

5. Tujuan

Pelatihan merupakan tujuan yang ditentukan, khususnya terkait dengan penyusunan rencana aksi (action play) dan penetapan sasaran.

6. Sasaran

Sasaran pelatihan harus ditentukan dengan kriteria yang terinci dan terukur. 
Berdasarkan latar belakang masalah, rumusan masalah, serta kajian pustaka yang diajukan, maka dapat dibuat kerangka berpikir sebagai berikut :

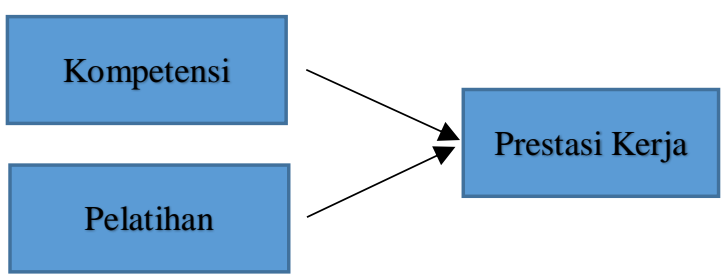

Gambar 1. Model Penelitian

Berikut adalah Hipotesis yang diajukan dalam penelitian ini :

1. Kompetensi berpengaruh positif dan signifikan terhadap Prestasi Kerja Relawan Pajak Tax Center Universitas Jember

2. Pelatihan berpengaruh positif dan signifikan terhadap Prestasi Kerja Relawan Pajak Tax Center Universitas Jember

\section{METODE PENELITIAN}

Penelitian ini merupakan jenis penelitian kuantitatif, yaitu metode penelitian yang berlandaskan pada filsafat positivisme, digunakan untuk meneliti pada populasi atau sampel tertentu, pengumpulan data menggunakan instrument penelitian, analisis data bersifat kuantitatif statistik, dengan tujuan untuk menguji hipotesis yang telah ditetapkan. Penelitian ini dilaksanakan pada Tax Center Universitas Jember. Pada penelitian ini, instrumen penelitian berupa kuesioner. Kuesioner tersebut akan dibagikan kepada responden sejumlah 59 orang relawan pajak tax center Universitas Jember, kemudian akan diolah secara statistik dengan software SPSS. Hasil olah data SPSS akan diinterpretasikan secara mendalam oleh tim peneliti, sehingga akan menghasilkan kesimpulan dan rekomendasi yang dapat digunakan sebagai acuan dalam pengambilan keputusan atau kebijakan terkait pengembangan sumberdaya manusia Relawan Pajak Tax Center Universitas Jember. Jenis data pada penelitian ini merupakan data kualitatif yang kemudian diolah menjadi data kuantitatif berupa angka, sesuai skala yang tertulis pada kuesioner penelitian. Sumber data dalam penelitian ini berupa data primer dan data sekunder. Data primer merupakan data yang diperoleh langsung dari responden, yaitu dalam bentuk kuesioner penelitian yang dibagikan kepada responden.

\section{HASIL DAN PEMBAHASAN}

Sebelum dianalisis lebih lanjut, penelitian ini terlebih dahulu akan diuji kualitas datanya terlebih dahulu yaitu menggunakan uji validitas dan reliabilitas.
Tabel 1. Hasil Uji Validitas

\begin{tabular}{|c|c|c|c|}
\hline Variabel & Item & Sig & Keterangan \\
\hline Kompetensi & 10 & 0,00 & Valid \\
\hline Pelatihan & 9 & 0,00 & Valid \\
\hline Prestasi & 12 & 0,00 & Valid \\
\hline
\end{tabular}

Sumber : Data SPSS diolah, 2020

Tabel 2. Hasil Uji Reliabilitas

\begin{tabular}{|c|c|c|c|}
\hline Variabel & $\begin{array}{c}\text { Cronbach's } \\
\text { Alpha }\end{array}$ & $\begin{array}{c}\text { Cronbach's } \\
\text { Alpha Based } \\
\text { on } \\
\text { Standardized } \\
\text { Items }\end{array}$ & $\begin{array}{c}\text { N of } \\
\text { Items }\end{array}$ \\
\hline Kompetensi & 0,644 & 0,730 & 10 \\
\hline Pelatihan & 0,870 & 0,874 & 9 \\
\hline Prestasi & 0,902 & 0,910 & 12 \\
\hline
\end{tabular}

Sumber : Data SPSS diolah, 2020

Berdasarkan Tabel 1, semua indikator setiap variabel signifikan di bawah 0,05. Pada Tabel 2. Uji Reliabilitas, semua indikator dalam variabel menghasilkan cronbach alpha di atas 0,07, sehingga dapat disimpulkan kualitas data sangat baik dan dapat dianalisis lebih lanjut. Kemudian dilakukan uji asumsi klasik untuk melihat lolos tidaknya data dalam uji normalitas, multikolonieritas, dan heteroskedastisitas. Berdasarkan uji asumsi klasik secara keseluruhan, terbukti bahwa data terdistribusi normal, tidak terjadi multikol dan heteroskeddastisitas. Oleh karena sudah lolos uji kualitas data dan uji asumsi klasik, maka penelitian ini akan masuk pada uji hipotesis baik secara parsial maupun simultan, sebagai berikut :

\section{Uji Hubungan Parsial}

Tabel 3. Uji Hubungan Parsial

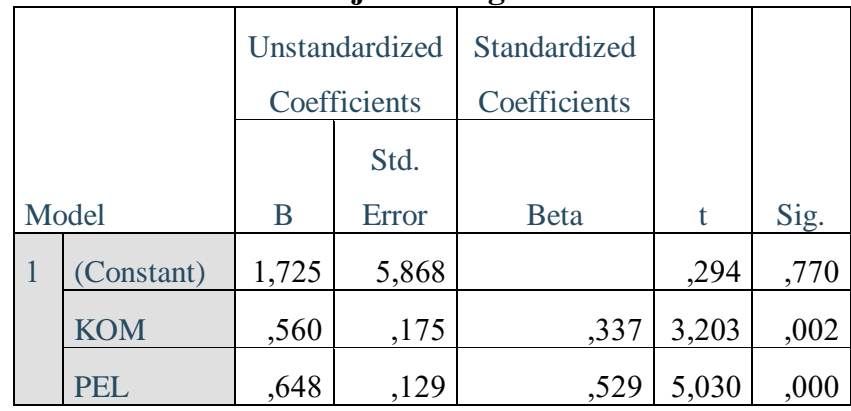

Sumber : Data SPSS diolah, 2020

Berdasarkan Tabel 3., maka persamaan regresi untuk penelitian ini adalah: $\mathrm{Y}=1,725+0,560 \mathrm{X} 1+0,648$ $\mathrm{X} 2$. Artinya bahwa setiap peningkatan satu unit kompetensi, maka prestasi kerja akan meningkat sebesar 0,560. Sedangkan apabila peningkatan satu unit pelatihan, maka prestasi kerja akan meningkat sebesar 0,648.

Variabel kompetensi memiliki tingkat signifikansi (sig. t) sebesar 0,002. Nilai ini lebih kecil dari $\alpha$ $(0,05)$, maka $\mathrm{H}_{0}$ ditolak dan menerima $\mathrm{H}_{1}$ yang berarti 
variabel kompetensi berpengaruh secara signifikan terhadap prestasi kerja Relawan Pajak Tax Center Universitas Jember. Artinya bahwa apabila kompetensi yang dimiliki oleh Relawan Pajak Tax Center meningkat, maka akan diikuti dengan meningkatnya prestasi kerja yang dimiliki. Begitupula sebaliknya.

Variabel pelatihan memiliki tingkat signifikansi (sig. t) sebesar 0,000. Nilai ini lebih kecil dari $\alpha(0,05)$, maka $\mathrm{H}_{0}$ ditolak dan menerima $\mathrm{H}_{2}$ yang berarti variabel pelatihan berpengaruh secara signifikan terhadap prestasi kerja Relawan Pajak Tax Center Universitas Jember. Artinya bahwa apabila pelatihan yang diikuti oleh Relawan Pajak Tax Center meningkat, maka akan diikuti dengan meningkatnya prestasi kerja yang dimiliki. Begitupula sebaliknya.

\section{Uji Hubungan Simultan}

Tabel 4. Uji Hubungan Simultan

\begin{tabular}{|c|c|c|c|c|c|c|}
\hline \multicolumn{2}{|c|}{ Model } & $\begin{array}{l}\text { Sum of } \\
\text { Squares }\end{array}$ & $\mathrm{df}$ & $\begin{array}{l}\text { Mean } \\
\text { Square }\end{array}$ & $\mathrm{F}$ & Sig. \\
\hline \multirow[t]{3}{*}{1} & $\begin{array}{l}\text { Regress } \\
\text { ion }\end{array}$ & 666,588 & 2 & 333,294 & 44,109 &, $000^{\mathrm{b}}$ \\
\hline & $\begin{array}{l}\text { Residu } \\
\text { al }\end{array}$ & 423,141 & 56 & 7,556 & & \\
\hline & Total & 1089,729 & 58 & & & \\
\hline
\end{tabular}

a. Dependent Variable: PRES

b. Predictors: (Constant), PEL, KOM

Sumber : Data SPSS diolah, 2020

Berdasarkan Tabel 4., nilai F hitung sebesar 44,109 dengan arah positif, serta nilai signifikansi sebesar 0.000 , dimana nilai signifikansi tersebut di bawah 0.05 . Sehingga dapat disimpulkan bahwa variabel kompetensi dan pelatihan, secara bersama- sama berpengaruh terhadap terhadap prestasi kerja Relawan Pajak Tax Center Universitas Jember, serta arah pengaruhnya bersifat positif. Apabila kompetensi dan pendidikan meningkat, maka akan meningkatkan prestasi kerja Relawan Pajak Tax Center Universitas Jember. Begitu pula sebaliknya, yaitu apabila kompetensi dan pelatihan secara bersama-sama menurun, maka akan berpengaruh terhadap turunnya prestasi kerja Relawan Pajak Tax Center Universitas Jember.

\section{Koefisien Determinasi}

Besarnya nilai koefisien Determinansi $\left(\mathrm{R}^{2}\right)$ menunjukkan tingkat pengaruh variabel independen terhadap dependen.
Tabel 5. Koefisien Determinasi

\begin{tabular}{|l|r|r|r|r|}
\hline $\begin{array}{l}\text { Mo } \\
\text { del }\end{array}$ & \multicolumn{1}{c|}{$\mathrm{R}$} & R Square & \multicolumn{1}{c|}{$\begin{array}{c}\text { Sdjusted R } \\
\text { Square }\end{array}$} & $\begin{array}{c}\text { Std. Error of } \\
\text { the Estimate }\end{array}$ \\
\hline 1 &, $782^{\mathrm{a}}$ &, 612 &, 598 & 2,749 \\
\hline
\end{tabular}

a. Predictors: (Constant), PEL, KOM

Sumber : Data SPSS diolah, 2020

Berdasarkan Tabel 5., nilai $R$ Square $\left(\mathrm{R}^{2}\right)$ adalah sebesar 0,598. Hal ini menunjukkan bahwa 59,8\% perubahan yang terjadi pada prestasi kerja Relawan Pajak Tax Center Universitas Jember dijelaskan oleh variabel bebas kompetensi dan pelatihan. Sedangkan sisanya sebesar 40,2 \% (100\% - 59,8\% = 40,2\%) dijelaskan oleh variabel yang tidak dibahas pada penelitian ini.

\section{KESIMPULAN}

Berdasarkan hasil penelitian mengenai pengaruh Kompetensi dan Pelatihan terhadap Prestasi Kerja Relawan Pajak Tax Center Universitas Jember, maka dapat disimpulkan bahwa secara parsial maupun simultan, kompetensi dan pelatihan berpengaruh secara signifikan dan positif terhadap prestasi kerja. Sehingga jika terjadi peningkatan kompetensi dan pelatihan, maka akan meningkatkan pula prestasi kerja. Begitupula sebaliknya, jika terjadi penurunan kompetensi dan pelatihan, maka akan diikuti pula dengan adanya penurunan prestasi kerja. Berdasarkan nilai $R$ Square $\left(\mathrm{R}^{2}\right)$ adalah sebesar 0,598. Hal ini menunjukkan bahwa $59,8 \%$ perubahan yang terjadi pada prestasi kerja Relawan Pajak Tax Center Universitas Jember dijelaskan oleh variabel bebas kompetensi dan pelatihan. Sedangkan sisanya sebesar $40,2 \%(100 \%-59,8 \%=40,2 \%)$ dijelaskan oleh variabel lain yang tidak dibahas pada penelitian ini.

\section{REFERENSI}

Aprilda. 2017. Pengaruh Kompetensi terhadap Prestasi Kerja Pegawai (Studi Pada Bagian Pengelolaan Keuangan Balai Pengembangan Pendidikan Nonformal dan Informasi Regional I Medan). Jurnal Administrasi Publik, Vol.3, No.2, 2017.

Boedijono, B., Wicaksono, G., Puspita, Y., Bidhari, S., Kusumaningrum, N., \& Asmandani, V. (2019). Efektifitas Pengelolaan Dana Desa Untuk Pembangunan Dan Pemberdayaan Masyarakat Desa di Kabupaten Bondowoso. 
Jurnal Riset Manajemen Dan Bisnis (JRMB) Fakultas Ekonomi UNIAT, 4(1), 9 - 20. https://doi.org/10.36226/jrmb.v4i1.237

Firstie, H.S. dan Madina, S. 2017. Pengaruh Gaya Kepemimpinan, Kompetensi dan Motivasi Kerja terhadap Kinerja Pegawai Negeri Sipil di Dinas Perhubungan Kabupaten Kapuas. Jurnal Kindal, Vol.13, No.4, Oktober 2017.

Hasibuan, Malayu. 2015. Manajemen Sumber Daya Manusia. Jakarta : Bumi Aksara.

Juned, A., dkk. 2016. Pengaruh Disiplin, Kompetensi dan Kepemimpinan terhadap Kinerja Pegawai Dinas Tenaga Kerja Kota Samarinda. EJournal Universitas 17 Agustus 1945 Samarinda.

Mangkunegara, Anwar Prabu. 2006. Manajemen Sumber Daya Manusia Strategik. Jakarta : Ghalia Indonesia.

Maulana, R.B. 2016. Pengaruh Motivasi Kerja dan Pelatihan (Diklat) dan Disiplin Kerja terhadap Kompetensi Pegawai dan Kinerja Pegawai. Jurnal Riset Bisnis dan Manajemen, Vol.4, No.3, 2016.

Nurasiah, Haslinda. 2016. Pengaruh Pelatihan Kerja dan Kompensasi terhadap Prestasi Kerja Karyawan Pada PT. Perkebunan Nusantara XIV (Pabrik Gula Takalar). E-Journal Universitas Islam Negeri Alauddin Makassar.

Peraturan Pemerintah Nomor 101 Tahun 2000 tentang Pendidikan dan Pelatihan Jabatan Pegawai Negeri Sipil (PNS).

Puspita, Yeni dan Galih Wicaksono. 2017. Analisis Potensi Pajak Restoran di Kabupaten
Banyuwangi (Studi Kasus Kecamatan Banyuwangi). Prosiding Seminar Nasional Pariwisata 2017 Universitas Jember - Jawa Timur.

Riyanda, M. 2017. Pengaruh Kompetensi dan Disiplin Kerja terhadap Kinerja Pegawai Pada Dinas Perizinan Kota Yogyakarta. E-Journal Universitas Negeri Yogyakarta.

Sedarmayanti. 2010. Manajemen Sumber Daya Manusia dan Produktivitas Kerja. Bandung : Ilham Jaya.

Sultana, S., dkk. 2012. Impact of Training on Employee Performance : A Study of Telecommunication Sector in Pakistan. Interdisciplinary Journal of Contemporary Research in Business, Vol.4, No.6.

Wahyudi, 2009. Kepemimpinan Kepala Sekolah dalam Organisasi Pembelajar (Learning Organization). Bandung : Alfabeta.

Wicaksono, Galih dan Tree Setiawan Pamungkas. 2017. Analisis Efektivitas dan Kontribusi Pajak Bumi dan Bangunan Perdesaan dan Perkotaan (PBB P2) terhadap Pendapatan Asli Daerah Kabupaten Jember. Jurnal STIE Semarang, Vol 9, Februari 2017.

Yunus, A.N.M. 2014. Pengaruh Kompetensi, Disiplin, dan Lingkungan Kerja terhadap Kinerja Pegawai Pada Biro Umum dan Perlengkapan Sekretariat Daerah Provinsi Sulawesi Selatan. E-Journal Universitas Hasanuddin Makassar. 